\title{
MulawarmanLawReview
}

\section{Legal Protection of Go-Jek Driver That Experiences Damages Due To The Fictive Order In Go-Food Menu In Go-Jek Aplication}

\author{
Aditya Hermawan ${ }^{1}$, Erna Susanti ${ }^{2}$, Syukri Hidayatullah ${ }^{3}$ \\ ${ }^{1}$ Alumni of Law faculty of Mulawarman University-Indonesia \\ E-mail: adityahermawan82@yahoo.co.id \\ ${ }^{2}$ Alumni of Law faculty of Mulawarman University-Indonesia \\ E-mail: r_nas77@rocketmail.com \\ ${ }^{3}$ Alumni of Law faculty of Mulawarman University-Indonesia \\ E-mail:syukri@fh.unmul.ac.id
}

\begin{abstract}
This research is proposed to answer two questions: Firstly, to find out the cause of fictitious orders experienced by Go-Jek drivers in the Go-food menu in Go-Jek app. Secondly, to know the legal protection of Go-Jek drivers who suffered losses due to a fictitious plane in the Go-food menu on the Go-Jek app. And the research is directed to educate the public the importance of Civil law which governs agreement in the life of society. This study uses socio-legal approach with a number of resource persons. The choice of approach to socio-legal does not mean disregarding doctrinal side support on the grounds that one of the aims of this study sees a set of positive norms in relation to Legal protection of Go-Jek drivers, including legal theory support with a view to verifying the implementation of law in practice (protection and responsible).
\end{abstract}

This study concludes that, Transactions using Go-Jek access has so far caused legal consequences among others who is responsible for the losses experienced by drivers, whether the Go-Jek party is responsible for the losses experienced drivers, including what kind of legal protection obtained by the driver when suffering application losses by irresponsible consumers. The factors of the emergence of fictitious orders are the existence of competitions between the Go-Jek driver, Go-Jek verification system is still weak, and the existence of bad faith in someone. Partnership agreement between PT. Go-Jek and Go-Jek's driver is a standard clause that created and provided without involving the Go-Jek drivers in which there is a clause of transfer of responsibility because of PT. Go-Jek as the Go-Jek application service manager will not be responsible if there is a loss caused by the use of Go-Jek application. The legal relations and responsibilities of the parties should be clearly stipulated in the partnership agreement between PT. GoJek Indonesia, and Partners are created based on mutual agreement and agreement between both parties. To minimize the losses experienced by Go-Jek drivers in service delivery for every use of consumer spending service must have a Go-Pay account, which expenditures can not be executed if the balance in the Go-Pay account is insufficient to make an expense transaction.

Keywords: Legal Protection; Fictitious; Order; Loss.

Citation: Susanti, Erna, Aditya Hermawan, and Syukri Hidayatullah. 2019. "Legal Protection of Go-Jek Driver That Experiences Damages Due To The Fictive Order In Go-Food Menu In Go-Jek Aplication". Mulawarman Law Review 3 (2), 124-32. https://doi.org/10.30872/mulrev.v3i2.117. 


\section{INTRODUCTION}

Perkembangan Bisnis di Indonesia saat ini bertumbuh pesat. Peluang bisnis di berbagai bidang semakin bertambah seiring meningkatnya kebutuhan masyarakat. Pelaku usaha mengembangkan usahanya secara inovatif dan kreatif agar mampu menghadapi persaingan antar pelaku usaha. Di era globalisasi, pelaku usaha mulai mengembangkan usaha mereka dengan memanfaatkan teknologi sebagai sarana.

Pengembangan sarana dan prasarana transportasi yang cepat sangat berperan penting sebagai penghubung. Tanpa adanya transportasi sebagai sarana penunjang tidak dapat diharapkan tercapai hasil yang memuaskan dalam pengembangan ekonomi suatu negara.

Kebutuhan sarana transportasi berbanding lurus dengan tingkat kepadatan penduduk di suatu wilayah. Perbandingan antara jumlah kendaraan yang tersedia sebagai angkutan umum dengan kebutuhan masyarakat sering tidak seimbang. Bukan hanya ketersediaan kendaraan yang menjadi alasan meningkatnya kebutuhan akan angkutan umum, tetapi efisiensi waktu dan kenyamanan untuk mendapat sarana transportasi berupa angkutan umum juga menjadi salah satu pertimbangan. Layanan jasa ojek berbasis online berhasil menawarkan berbagai keunggulan dibanding angkutan umum lainnya yang tersedia saat ini. Pertumbuhan layanan ojek online semakin pesat. Dalam waktu singkat, layanan ojek online ini berhasil menjaring ribuan tenaga kerja di Indonesia untuk menjadi pengemudi ojek (driver) dan mendapat pasaran yang begitu luas dalam mengembangkan usahanya.

Go-Food merupakan layanan yang berada pada menu aplikasi Go-Jek dengan menawarkan layanan pesan antar makanan memiliki ribuan partner outlet restoran yang telah terdaftar di dalam aplikasi Go-Jek. Cukup memilih restoran pada aplikasi, memilih menu makanan yang diinginkan dan kemudian muncul total harga yang harus di bayarkan. Informasi kemudian terkirim ke server Go-Jek, dan sistem informasi GoJek meneruskan informasi ke pengemudiyang berada di sekitar lokasi. Dalam menjalankan usaha di berbagai bidang, Go-Jek bekerja sama dengan pengemudi. Perusahan Go-Jek melakukan perjanjian kemitraan dengan para penyedia jasa dalam hal ini pengemudi Go-Jek. Di satu sisi, pada dasarnya keberadaan fitur Go-Food pada aplikasi Go-Jek akan mempermudah layanan pesan-antar makanan bagi konsumen yang tidak dapat membeli makanan secara langsung di restoran yang tidak memiliki layanan pesan-antar makanan sendiri. Di sisi lain, kemudahan bagi konsumen disalahgunakan dengan pesanan fiktif yang membawa kerugian bagi para pengemudi apabila konsumen tidak membayar lunas pesanan tidakl dicantumkan dalam perjanjian kemitraan antara pihak gojek dan pengemudi.

Permasalahan hukum yang dibahas dalam tulisan ini adalah bahwa transaksi menggunakan akses Go-Jek selama ini menimbulkan akibat hukum di antaranya siapa yang bertanggung jawab atas kerugian yang dialami pengemudi, apakah pihak Go-Jek bertanggung jawab atas kerugian yang dialami pengemudi, termasuk perlindungan hukum seperti apa yang diperoleh pengemudi saat menderita kerugian akibat aplikasi oleh konsumen yang tidak bertanggung jawab. 


\section{METHOD}

penelitian ini merupakan penelitian dengan menggunakan metode socio-legal research maka pendekatan penelitian menggunakan pendekatan studi kasus hukum perlindungan hukum terhadap driver Go-Jek yang mengalami kerugian akibat adanya pesanan fiktif di aplikasi Go-Food ditinjau dari mengkaji kendala dalam adanya pesanan fiktif serta perlindungan hukum yang diterima driver saat menderita kerugian akibat aplikasi oleh konsumen yang tidak bertanggung jawab.

\section{DISCUSSION}

\section{Faktor penyebab adanya pesanan fiktif pada menu Go-Food di aplikasi Go-Jek}

Go-Food merupakan Salah satu layanan andalan dalam aplikasi Go-Jek. Perusahaan Go-Jek telah bekerjasama dengan lebih dari 30.000 restoran di Indonesia untuk dimasukkan ke dalam salah satu fitur dalam aplikasi Go-Jek yaitu Go-Food. ${ }^{1}$ Meskipun telah bekerja sama dengan banyak restoran tidak berarti bahwa layanan Go-Food bebas dari masalah.

Proses pemesanan makanan dalam aplikasi Go-Jek adalah: (1) Konsumen membuka aplikasi Go-Jek pada smartphone, kemudian masuk ke dalam layanan Go-Food. Di dalam layanan Go-Food akan muncul beberapa restoran yang telah bekerja sama dengan Go-Food; (2) Konsumen memilih restoran kemudian memilih menu makanan yang diinginkan pada aplikasi tersebut. Selain daftar menu makanan, gambar makanan, di dalam aplikasi juga tersedia harga perkiraan masing-masing makanan tersebut; (3) Apabila konsumen telah selesai memilih makanan yang akan dipesan di restoran, maka selanjutnya konsumen melakukan konfirmasi pemesanan dengan memasukkan alamat tujuan pemesanan. Secara otomatis biaya pengantaran telah terkalkulasi dengan jarak tempuh dari restoran ke alamat tujuan konsumen ketika konsumen memasukkan alamat tujuan pemesanan dan juga telah terakumulasi dengan harga perkiraan makanan yang dipesan; (4) Kemudian konsumen memilih metode pembayaran. Ada 2 metode pembayaran untuk layanan Go-Food yaitu pembayaran secara tunai dan pembayaran melalui Go-Pay. Saat ini apabila menggunakan pembayaran melalui Go-Pay, konsumen hanya perlu membayar harga makanan yang dipesan dan biaya pengiriman makanan gratis; (5) Setelah melakukan konfirmasi pemesanan dengan memasukkan alamat, melihat harga perkiraan makanan dan biaya pengantaran kemudian memilih metode pembayaran, maka selanjutnya konsumen melakukan pemesanan. Setelah itu sistem akan langsung menerima informasi kemudian informasi tersebut disebar ke driver melalui aplikasi; (6) Apabila salah seorang driver telah lebih dulu menerima untuk melakukan pekerjaan tersebut, maka secara otomatis driver yang lain tidak dapat menerima pemesanan tersebut. (7) Driver yang menerima pemesanan makanan melalui aplikasi kemudian mengonfirmasi kepada konsumen yang memesan dengan cara menghubungi nomor telepon pemesan yang diperoleh melalui aplikasi. Ketika pemesanan berlangsung antara konsumen dan driver yang menerima dan melakukan pemesanan masing-masing saling mengetahui

\footnotetext{
${ }^{1}$ https://www.google.co.id/amp/s/obendon.com/2015/04/01/gofood/amp/ diakses pada hari Jum'at tanggal 23 Febuari 2018. Pukul 11.00 wita
} 
data diri pribadi, data pribadi yang di maksud adalah nama dan nomor telepon masingmasing pihak, data tersebut diperoleh dari aplikasi gojek. (8) Setelah driver melakukan konfirmasi untuk melakukan pembelanjaan makanan, maka driver kemudian ke restoran yang dimaksud dan membeli makanan yang diinginkan oleh konsumen. Saat pembelanjaan di restoran, terlebih dahulu driver menggunakan dananya untuk membeli makanan tersebut. (9) Setelah pembelanjaan di restoran driver kemudian mengantar makanan yang di pesan. Kemudian setelah sampai di tempat tujuan, driver kemudian menyerahkan makanan yang dipesan, dan konsumen membayar harga makanan dan biaya pengiriman. ${ }^{2}$

Selain masalah di atas, terdapat juga adanya pesanan fiktif yang dialami driver Go-Jek yang menimbuklan kerugian pada driver Go-Jek. Menurut hasil wawancara dari penulis yang dilakukan kepada 1 staff PT Go-Jek Indonesia bagian verifikasi, 10 orang driver Go-Jek, ditemukan penyebab/atau faktor adanya pesanan fiktif, menurut hasil wawancara dari penulis yang dilakukan kepada PT. Go-Jek, terdapat persaingan diantara driver dan sistem verifikasi Go-Jek yang lemah.

Faktor persaingan diantara driver. Driver menggunakan dua ponsel dengan dua aplikasi di dalamnya di satu ponsel dia berperan sebagai pelanggan, dan di ponsel lainnya berperan sebagai driver tindakan ini semata-mata bertujuan mendapatkan bonus yang besar karena merekam jumlah pelanggan yang diantarkan oleh driver. Semakin banyak laporan pelanggan, semakin besar bonus yang didapatkan. banyaknya jumlah driver Go-Jek yang berada saat ini membuat para driver berebut dalam mengambil pesanan menimbulkan persaingan antara driver dalam mencari pesanan pada konsumen.

Faktor Sistem verifikasi Go-Jek lemah, selama ini pihak Go-Jek hanya mengandalikan verivikasi melalui nomor telepon memudahakn orang membuat akun dengan identitas yang berbeda-beda dengan membeli nomor baru seseorang sudah bisa membuat akun dengan nama baru atau identitas yang berbeda pula tidak ada prosedur yang ketat dalam proses pembuatan akun misalakn menyertakan nomor KTP, nomor kartu keluarga, nomor mahasiswa atau yang lain yang dapat membuat verivikasi pada pembuatan akun dengan jelas mengetahui identitas pembuat akun tersebut.

Menurut hasil wawancara dari penulis yang dilakukan kepada driver Go-Jek dapat disimpulkan bahwa adanya itikad tidak baik yaitu adanya maksud tidak baik yang dilakukan oleh orang lain dengan maksud tertentu dengan sengaja atau dengan maksud tersendiri yang menimbulkan kerugian. Kebanyakan yang dialami para driver saat menerima pesanan adalah alamat dan identitas yang di berikan tidak benar saat pemesanan.

\section{Perlindungan Hukum Kepada Driver Go-Jek Pada Layanan Go-Food Pada Aplikasi Go-Jek}

Setiap hubungan hukum harus mendapatkan perlindungan hukum. Perlindungan hukum diartikan sebagai suatu bentuk tindakan atau perbuatan hukum yang diberikan kepada subjek hukum sesuai dengan hak dan kewajibannya berdasarkan hukum.

${ }^{2}$ http://repository.unhas.ac.id/bitstream/handle/123456789/23551/SKRIPSI\%LENGKAP.pdf?sequence=1 diakses pada hari Rabu, tanggal 31 Januari 2018. Pukul 21.00 wita 
Perlindungan hukum yang diberikan kepada subjek hukum baik berupa tindakan preventif maupun represif. ${ }^{3}$

Soetjipto Rahardjo mengemukakan bahwa perlindungan hukum adalah adanya upaya melindungi kepentingan seseorang dengan cara mengalokasikan suatu kekuasaan kepadanya untuk bertindak dalam kepentingan tersebut. Selanjutnya dikemukakan pula bahwa salah satu sifat dan sekaligus merupakan tujuan dari hukum adalah memberikan perlindungan (pengayoman) kepada masyarakat. Oleh karena itu, perlindungan hukum terhadap masyarakat tersebut harus diwujudkan dalam bentuk adanya kepastian hukum. ${ }^{4}$

Berdasarkan perjanjian elektronik kerjasama kemitraan dapat diketahui bahwa aplikasi Go-Jek yang digunakan oleh konsumen tidak hanya diurus oleh satu pihak melainkan ada beberapa pihak. Pihak dalam perjanjian tersebut adalah PT AKAB, GI dan Mitra.

PT. Aplikasi Karya Anak Bangsa (AKAB) adalah pihak yang membuat, memiliki dan mengurus aplikasi Go-Jek yang dimanfaatkan konsumen yang telah terdaftar untuk memperoleh jasa layanan antar-jemput barang dan/ atau orang, layanan pesan antar barang ataupun jasa lainnya dengan kendaraan bermotor roda dua maupun roda empat atau jasa lainnya sehubungan dengan aplikasi Go-Jek. aplikasi Go-Jek adalah aplikasi elektronik milik AKAB yang dapat dimanfaatkan setiap orang (konsumen) untuk memperoleh jasa layanan maupun pihak-pihak ketiga yang bekerja sama dengan GI ataupun AKAB sebagai wadah untuk menyalurkan jasa untuk antar-jemput barang dan/atau orang layanan pesan-antar barang dengan kendaraan bermotor roda dua maupun roda empat atau jasa lainnya yang terkait.

PT. Go-Jek Indonesia (GI) adalah sebuah perusahaan yang mengelola kerjasama dengan mitra dan menyediakan jasa manajemen operasional para mitra sehubungan dengan penggunaan aplikasi Go-Jek.

Mitra adalah pihak yang melaksanakan antar-jemput barang dan/atau orang, pesanantar barang yang sebelumnya telah dipesan oleh konsumen, atau jasa lainnya melalui aplikasi Go-Jek dengan menggunakan kendaraan bermotor roda dua yang dimiliki oleh mitra sendiri. Setiap mitra akan mendapatkan akun atas nama mitra setelah mendaftarkan diri pada aplikasi Go-Jek.

Mitra harus menjalankan tugas dengan sebaik-baiknya yang diterima dari aplikasi GoJek. Hal tersebut merupakan tanggung jawab berdasarkan perjanjian untuk melakukan suatu hubungan pekerjaan. Ketika mitra tidak dapat melakukan tugasnya dengan baik, maka tentu saja mitra harus bertanggung jawab sesuai dengan hal yang telah diperjanjikan. Namun ketika mitra telah melakukan tugasnya dalam pelayanan aplikasi Go-Food sesuai apa yang telah diperjanjikan, dan dalam pelaksanaan pengantarannya mitra tidak dapat menghubungi konsumen yang melakukan pemesanan (dalam hal ini konsumen tidak lagi memiliki itikad baik dalam melakukan pemesanan), maka sangat

\footnotetext{
${ }^{3}$ http://tesishukum.com/pengertian-perlindungan-hukum-menurut-para-ahli/ diakses pada hari Sabtu tanggal 4 Febuari 2018. pukul 08.30 wita.

${ }^{4}$ Soetjipto. 1983. Permasalahan Hukum Di Indonesia, Alumni, Bandung.
} 
tidak adil ketika mitra harus menanggung segala kerugian yang ditimbulkan sendiri mengingat kesalahan yang terjadi bukan merupakan akibat dari kesalahan mitra. Mitra bukanlah satu-satunya pelaku usaha dalam proses pelayanan aplikasi Go-Food, dan hubungan hukum para pihak berdasarkan perjanjian kemitraan.

Dalam perjanjian elektronik kerjasama kemitraan yang dibuat antara pihak PT AKAB, PT GI dan Mitra dapat dilihat hubungan kerja sama antara para pihak. Hal ini sangat penting untuk mengetahui siapa saja yang bertanggung jawab atas pelaksanaan layanan terkait dengan aplikasi Go-Jek. Selain itu PT AKAB dan PT GI juga memonitor kinerja mitra dalam melakukan pelayanan jasa, baik itu memonitor posisi mitra saat melakukan pelayanan dan tanggapan konsumen terhadap kualitas layanan yang diberikan oleh mitra.

Namun di dalam perjanjian diatur tentang ketentuan pihak mana yang akan bertanggung jawab apabila terdapat kesalahan yang dilakukan oleh konsumen. Di dalam perjanjian kemitraan tersebut terdapat klausul yang menyatakan "Dengan ini mitra menyetujui bahwa PT GI maupun PT AKAB tidak bertanggung jawab atas setiap kerugian termasuk kerugian tidak langsung yang meliputi kerugian keuntungan, kehilangan data, cidera pribadi, atau kerusakan property sehubungan dengan, atau diakibatkan oleh penggunaan aplikasi Go-Jek, maupun penyediaan jasa oleh mitra kepada konsumen. Mitra menyetujui bahwa PT AKAB tidak bertanggung jawab atas kerusakan, atau kewajiban, atau kerugian yang timbul karena penggunaan atau ketergantungan mitra terhadap aplikasi Go-Jek atau ketidak mampuan mitra mengakses atau menggunakan aplikasi Go-Jek". Sesuai dengan asas pacta sun servanda dalam Pasal 1338 KUHPerdata, perjanjian kemitraan antara PT. Go-Jek dengan driver berlaku sebagai Undang-Undang bagi mereka yang membuatnya.

Tetapi dalam konteks pertanggung jawaban hukum keperdataan Pasal 1366 KUHPerdata menyatakan: "setiap orang bertanggung jawab tidak saja untuk kerugian yang disebabkan karena perbuatannya, tetapi juga untuk kerugian yang disebabkan karena kelalaian atau kurang hati-hatinya."

Lebih lanjut pada Pasal 1367 KUHPerdata menyebutkan: "seorang tidak saja bertanggung jawab untuk kerugian yang disebabkan karena perbuatannya sendiri, tetapi juga untuk kerugian yang disebabkan karena perbuatan orang-orang yang menjadi tanggungannya, atau disebabkan oleh orang-orang yang berada dibawah pengawasannya."

Tentunya para pihak telah memiliki tugas masing-masing sehubungan dengan penyelenggaraan aplikasi Go-Jek dengan baik. Hal ini sangat jelas bahwa antara mitra, PT AKAB dan PT GI memiliki tanggung jawab sesuai dengan tugasnya untuk mempertanggung jawabkan secara hukum bilamana terdapat kesalahan atau kelalaian yang menimbulkan kerugian terhadap pihak lain. Sebagaimana sesuai dengan kedudukan hukum yang tercantum pada ketentuan umum perjanjian kerjasama kemitraan Go-Jek bahwa "PT AKAB adalah pemilik Aplikasi Go-Jek yang dimanfaatkan konsumen yang telah terdaftar untuk memperoleh jasa layanan antar-jemput barang dan atau orang, layanan pesan antar barang ataupun jasa lainnya dengan kendaraan bermotor roda dua maupun roda empat atau jasa lainnya; GI (Go-Jek Indonesia) adalah 
perusahaan yang melakukan kegiatan usaha sebagai pengelola penyedia jasa pihak kedua yang bekerja sama dengan PT AKAB; Mitra adalah pihak yang melaksanakan antar-jemput barang dan/atau orang, pesan antar barang yang sebelumnya telah dipesan oleh konsumen, atau jasa lainnya melalui aplikasi Go-Jek dengan menggunakan kendaraan bermotor yang dimiliki oleh mitra sendiri. Sehingga meskipun dalam perjanjian telah diatur tentang pengalihan kerugian ke pihak mitra, dalam kasus seperti yang telah dijelaskan sebelumnya pihak PT AKAB dan PT GI harus bertanggung jawab terhadap mitra yang mengalami kerugian diluar kesalahannya. Karena sesuai dengan bentuk tugas dan tanggung jawab sehubungan dalam penyelenggaraan aplikasi Go-Jek dengan baik, tugas untuk mengontrol, mengawasi serta mengevaluasi apakah suatu pesanan itu fiktif atau tidak adalah tugas dan tanggung jawab dari PT AKAB maupun PT. Go-Jek selaku penyedia jasa dan atau pengelola jasa layanan aplikasi Go-Jek.

\section{Keabsahan Perjanjian Baku/klausula Baku Pada Perjanjian Go-Jek Ditinjau Dari KUHPerdata}

Perjanjian baku adalah konsep janji-janji tertulis disusun tanpa membicarakan isinya dan lazimnya dituangkan ke dalam perjanjian yang sifatnya tertentu. Menurut Abdul Khadir Muhammad, perjanian baku dialih bahasakan dari istilah asing yakni 'standard contract'. ${ }^{5}$ dimana baku atau standar memiliki arti sebagai tolak ukur, yakni pedoman atau patokan bagi konsumen dalam mengadakan hubungan hukum dengan pihak pengusaha.

Berdasarkan pada klausul perjanjian,dapat di pahami bahwa hubungan hukum para pihak merupakan suatu hubungan mitra kerjasama PT GI, PT AKAB dan Mitra dalam perjanjian kemitran terdapat klausula baku yang menyatakan pengalihan tanggung jawab atau resiko terhadap kerugian akibat penggunaan aplikasi yang dialami driver Go-Jek kepada driver Go-Jek yaitu adalah: "Dengan ini mitra menyetujui bahwa Go-Jek maupun PT AKAB tidak bertanggung jawab atas setiap kerugian termasuk kerugian tidak langsung yang meliputi kerugian keuntungan, kehilangan data, cidera pribadi, atau kerusakan property sehubungan dengan, atau diakibatkan oleh penggunaan aplikasi Go-Jek, maupun penyediaan jasa oleh mitra kepada konsumen. Mitra menyetujui bahwa PT AKAB tidak bertanggung jawab atas kerusakan, atau kewajiban, atau kerugian yang timbul karena penggunaan atau ketergantungan mitra terhadap aplikasi Go-Jek atau ketidak mampuan mitra mengakses atau menggunakan aplikasi Go-Jek.

Isi perjanjian tersebut menjelaskan bahwa PT AKAB dan PT GI tidak bertangung jawab akibat kerugian yang dialami driver akibat penggunaan atau akibat mengakses aplikasi Go-Jek dan membebankan kepada driver padahal pada bunyi perjanjian sebelumnya telah di jelaskan bahwa PT AKAB adalah pihak pemilik aplikasi Go-Jek dan PT GI adalah perusahaan yang mengelola.

\footnotetext{
${ }^{5}$ http://repository.usu.ac.id/bitstream/handel/123456789/44231/chapter\%20II.p;jsessionid=0003EC77B 06E2971CBOFF13186A61979?sequence=3 diakses pada hari Kamis tanggal 22 Febuari 2018. pukul 15.00 wita.
} 
Perjanjian yang tertera dalam perjanjian kemitraan adalah suatu bentuk perjanjian yang baku. Didalam perjanjian tersebut klausula-klausula baik yang memberatkan pihak pengguna jasa atau tidak. Terhadap klausul yang bersifat pengalihan tanggung jawab/memberatkan. Apabila dikaitkan dengan teori dalam KUHPerdata perjanjian semacam itu termasuk dalam jenis perjanjian innominaat(diluar KUHPerdata).

\section{Implikasi Pesanan Fiktif Pada Menu Go-Food Pada Aplikasi Go-Jek}

Dampak dari pesanan fiktif adalah driver Go-Jek mengalami kerugian sedangkan tidak adanya mekanisme ganti rugi yang diberikan pihah PT.Go-Jek membuat driver menanggung kerugian yang dialami karena pada proses pemesanan biaya ditanggung driver terlebih dahulu sebelum pesanan sampai kepada konsumen. Perbuatan melawan hukum menurut KUHPerdata, perbuatan melawan hukum menurut Pasal 1365 KUH Perdata, yang berbunyi: "Tiap perbuatan melawan hukum yang membawa kerugian kepada seorang lain, mewajibkan orang yang karena salahnya menerbitkan kerugian untuk mengganti kerugian tersebut."

Sedangkan Pasal 1366 KUHPerdata, menyebutkan:" "Setiap orang bertanggung-jawab tidak saja untuk kerugian yang disebabkan karena perbuatannya, tetapi juga untuk kerugian yang diesbabkan karena kelalaian atau kurang hati-hatinya". Lebih lanjut, Pasal 1367 KUHPerdata, menyebutkan:7 "Seorang tidak saja bertanggung-jawab untuk kerugian yang disebabkan karena perbuatannya sendiri, tetapi juga untuk kerugian yang disebabkan karena perbuatan orang-orang yang menjadi tanggungannya, atau disebabkan oleh orang-orang yang berada di bawah pengawasannya".

Berdasarkan kutipan pasal tersebut di atas, secara umum memberikan gambaran mengenai batasan ruang lingkup akibat dari suatu perbuatan melawan hukum. Akibat perbuatan melawan hukum secara yuridis mempunyai konsekwensi terhadap pelaku maupun orang-orang yang mempunyai hubungan hukum dalam bentuk pekerjaan yang menyebabkan timbulnya perbuatan melawan hukum. Jadi, akibat yang timbul dari suatu perbuatan melawan hukum akan diwujudkan dalam bentuk ganti kerugian terehadap korban yang mengalami.

\section{CONCLUSION}

Faktor penyebab terjadinya pesanan fiktif adalah karena tidak adanya kepastian hukum. lemahnya system verifikasi aplikasi Go-Jek dalam proses registrasi akun pengguna Aplikasi Go-Jek, sehingga setiap orang dapat memiliki akun Aplikasi Go-Jek tanpa identitasi yang jelas.

Perlindungan hukum terhadap driver Go-Jek yang mengalami pesanan fiktif belum terlindungi dengan jelas pihak siapa yang harus bertanggung jawab atas kerugian yang dialaminya. Berdasarkan perjanjian kemitraan antar driver (mitra) dengan pihak PT GI/Go-Jek dan atau PT AKAB (Aplikasi karya anak bangsa) selaku pengelola dan penyedia jasa layanan aplikasi Go-Jek, pihak PT. Go-Jek dan/atau AKAB (pemilik

\footnotetext{
${ }^{6} \mathrm{https} / / /$ legalize21.wordpress.com/tag/pasal-1243-kuhperdata/ diakses pada hari Selasa tanggal 20 Maret 2018. Pukul 02.39 wita.

${ }^{7}$ lbid.
} 
Aplikasi Go-Jek) mengalihkan tanggung jawab kerugian kepada mitra (driver Go-Jek). Berdasarkan kedudukan tugas dalam penyelenggaraan aplikasi Go-Jek yang baik yang bertanggung jawab atas kerugian yang diterita oleh mitra (driver) adalah PT AKAB dan/atau PT. Go-Jek itu sendiri, karena satu sisi mitra (driver) merupakan pelaku usaha sekaligus konsumen atas aplikasi penyedia jasa layanan antar-jemput barang dan/atau orang yang menderita kerugian bukan karena kesalahan driver (mitra) melakukanan kelalaian pihak penyedia dan/atau pengelola layanan jasa aplikasi Go-Jek dalam memverifikasi pesanan konsumen. Selain itu dari pihak konsumen juga harus bertindak lebih bijak dalam penggunaan jasa layanan aplikasi seperti pada aplikasi Go-Jek karena dengan tindakan atau adanya itikad tidak baik berdampak kerugian pada orang lain dimana driver dalam hal ini yang mengalami kerugian akibat adanya pesanan fiktif.

\section{RECOMENDATION}

Seharusnya adanya hubungan hukum dan tanggung jawab para pihak secara jelas diatur di dalam perjanjian kemitraan antara PT. Go-Jek Indonesia, dan Mitra di buat berdasarkan kesepakatan dan persetujuan bersama antara kedua belah pihak khususnya terkait bagaimana bentuk pertanggung jawaban hukum keperdataan dan perlindungan hukum ketika Mitra dalam melaksanakan kegiatan pelayanan mengalami kerugian yang diakibatkan oleh adanya pesanan fiktif.

Untuk meminimalisir kerugian yang dialami oleh driver Go-Jek dalam pelaksanaan pelayanan, seharusnya pihak PT. Go-Jek Indonesia tidak lagi menerapkan sistem driver membayar terlebih dahulu segala pembelanjaan konsumen menggunakan dana pribadi driver. Untuk setiap penggunaan pelayanan pembelanjaan konsumen harus memiliki akun Go-Pay, yang dimana pembelanjaan tidak dapat dilaksanakan apabila saldo di dalam akun Go-Pay tersebut tidak mencukupi untuk melakukan transaksi pembelanjaan.

\section{REFERENCES}

Soetjipto. 1983. Permasalahan Hukum Di Indonesia, Alumni, Bandung. https://www.google.co.id/amp/s/obendon.com/2015/04/01/gofood/amp/ diakses pada hari Jum'at tanggal 23 Febuari 2018. Pukul 11.00 wita

http://repository.unhas.ac.id/bitstream/handle/123456789/23551/SKRIPSI\%LENGKAP. pdf?sequence $=1$ diakses pada hari Rabu, tanggal 31 Januari 2018. Pukul 21.00 wita

http://tesishukum.com/pengertian-perlindungan-hukum-menurut-para-ahli/ diakses pada hari Sabtu tanggal 4 Febuari 2018. pukul 08.30 wita.

http://repository.usu.ac.id/bitstream/handel/123456789/44231/chapter\%20II.p;jsessi onid=0003EC77B06E2971CB0FF13186A61979 ?sequence $=3$ diakses pada hari Kamis tanggal 22 Febuari 2018. pukul 15.00 wita.

https://legalize21.wordpress.com/tag/pasal-1243-kuhperdata/ diakses pada hari Selasa tanggal 20 Maret 2018. Pukul 02.39 wita. 